\title{
Rilievo dell'ex Ospedale dello Spirito Santo a Lecce per la valutazione e riduzione del rischio sismico
}

\author{
Marco Aprea \\ Giovanna Cacudi \\ Gabriele Rossi \\ Francesca Sisci
}

Abstract

II contributo che qui si presenta intende evidenziare il ruolo assunto dalle attuali tecniche di rilievo nella conoscenza di un manufatto per la loro capacità di fornire una completa descrizione stereometrica della fabbrica architettonica con la qualità e l'accuratezza necessaria alle attività di tutela e salvaguardia del patrimonio culturale dal rischio sismico.

II quadro normativo e le linee guide per la valutazione e riduzione del rischio sismico riconoscono infatti tale ruolo conoscitivo alle operazioni di rilievo e, su questa base di conoscenza, promuovono interventi di prevenzione e miglioramento nel rispetto della natura del bene.

La prevenzione dal rischio sismico, ancora poco attuata, ha nell'esperienza che qui si presenta - il Complesso dell'ex Ospedale dello Spirito Santo a Lecce - un caso significativo attestante il graduale passaggio dalla logica dell'emergenza a quella della prevenzione e della tutela da parte delle istituzioni preposte.

Parole chiave

rilievo architettonico integrato, patrimonio architettonico, Ospedale Spirito Santo, Lecce.

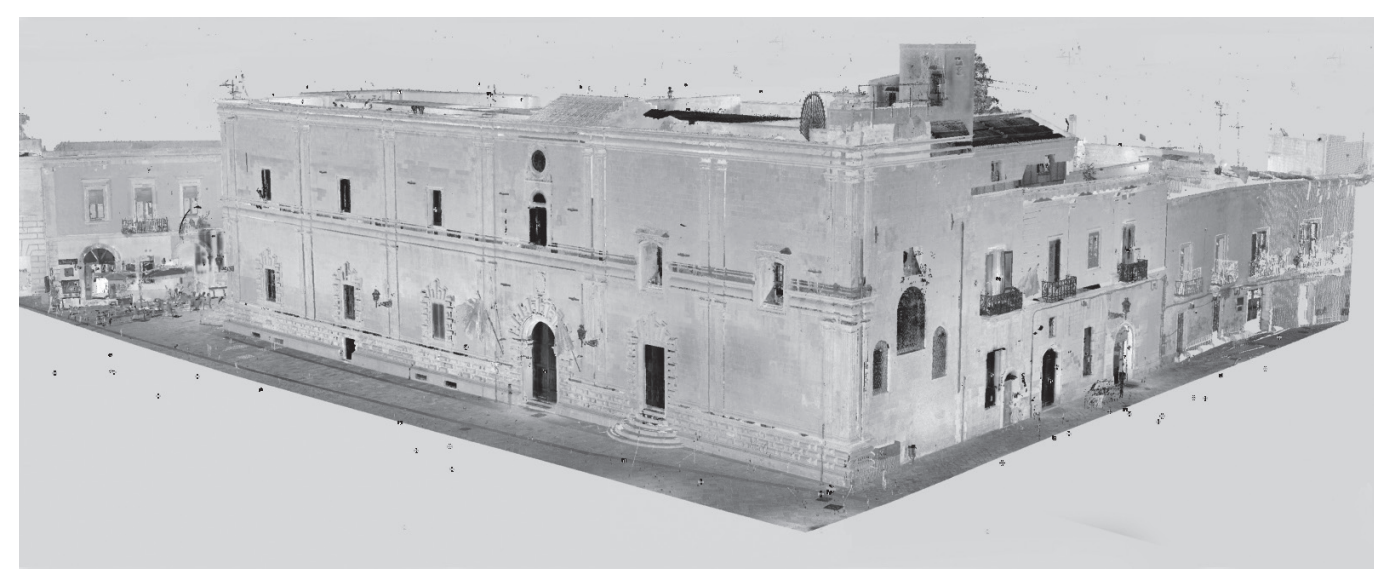


La salvaguardia del patrimonio culturale dal rischio sismico rientra tra le attività di prevenzione e nel programma di monitoraggio dello stato di conservazione dei beni architettonici tutelati. Le Linee guida per la valutazione e riduzione del rischio sismico del patrimonio culturale tutelato - introdotte dal DPCM del 9 febbraio 20I I e in accordo con le Nuove Norme Tecniche per le Costruzioni del 2008 [I] - sono state redatte "con l'intento di specificare un percorso di conoscenza, valutazione della sicurezza sismica e progetto degli eventuali interventi, concettualmente analogo a quello previsto per le costruzioni non tutelate, ma opportunamente adattato alle esigenze e peculiarità del patrimonio culturale; la finalità è quella di formulare, nel modo più oggettivo possibile, il giudizio finale sulla sicurezza e sulla conservazione garantite dall'intervento di miglioramento sismico. In particolare, il documento è riferito alle sole costruzioni in muratura" [2].

La "Conoscenza del manufatto" - titolo del capitolo 4 delle citate linee guida - è "presupposto fondamentale sia ai fini di una attendibile valutazione della sicurezza sismica attuale sia per la scelta di un efficace intervento di miglioramento". II percorso di conoscenza suggerito può avere differenti livelli a seconda dell'accuratezza nelle operazioni di rilievo ed in particolare è espressamente previsto "il rilievo geometrico della costruzione nello stato attuale, inteso come completa descrizione stereometrica della fabbrica" quale supporto fondamentale per definire la geometria del modello da utilizzare nell'analisi sismica. L'accezione stereometrica assegnata alla descrizione della fabbrica è da interpretare in riferimento all'etimologia della parola di origine greca cui corrisponde il significato di solido e misura e quindi il concetto di misura del solido. Una descrizione stereometrica si deve intendere come una conoscenza completa della geometria del solido della fabbrica. Tuttavia, insieme al rilievo geometrico, le linee guida prevedono anche il rilievo dei fenomeni fessurativi e deformativi, l'analisi storica degli eventi e degli interventi subiti, il rilievo materico costruttivo e lo stato di conservazione, il tutto quale base conoscitiva per le successive fasi di valutazione della sicurezza e il miglioramento sismico del manufatto.

In questo quadro di prevenzione e monitoraggio la Soprintendenza Archeologia Belle Arti e Paesaggio per le provincie di Brindisi, Lecce eTaranto - nell'ambito dei fondo introdotto con la L. 232 del I I dicembre 2016 Bilancio di previsione dello Stato per l'anno finanziario 2017 e bilancio pluriennale per il triennio 2017-2019 al comma I40, lettera h) [3] - ha promosso

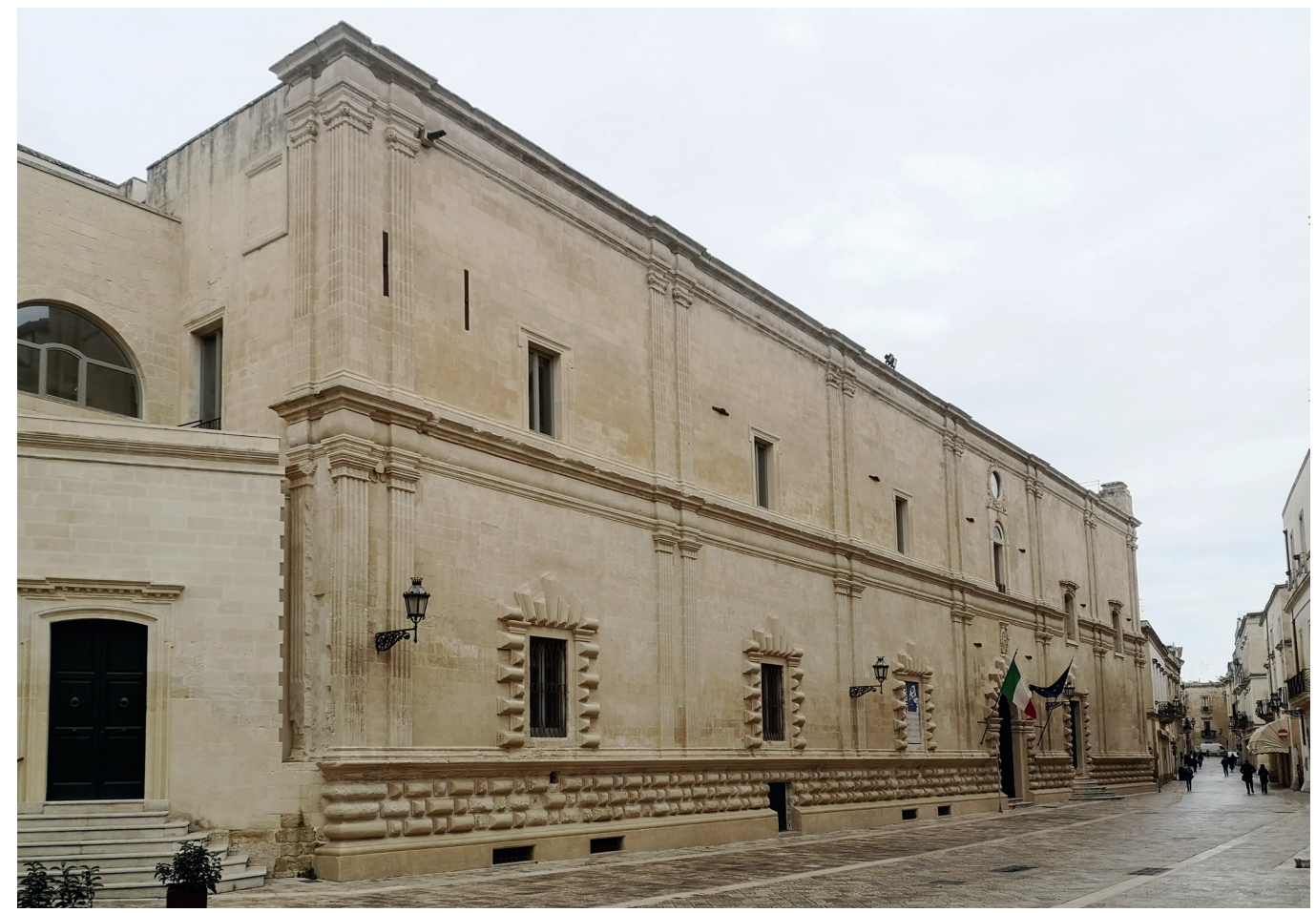




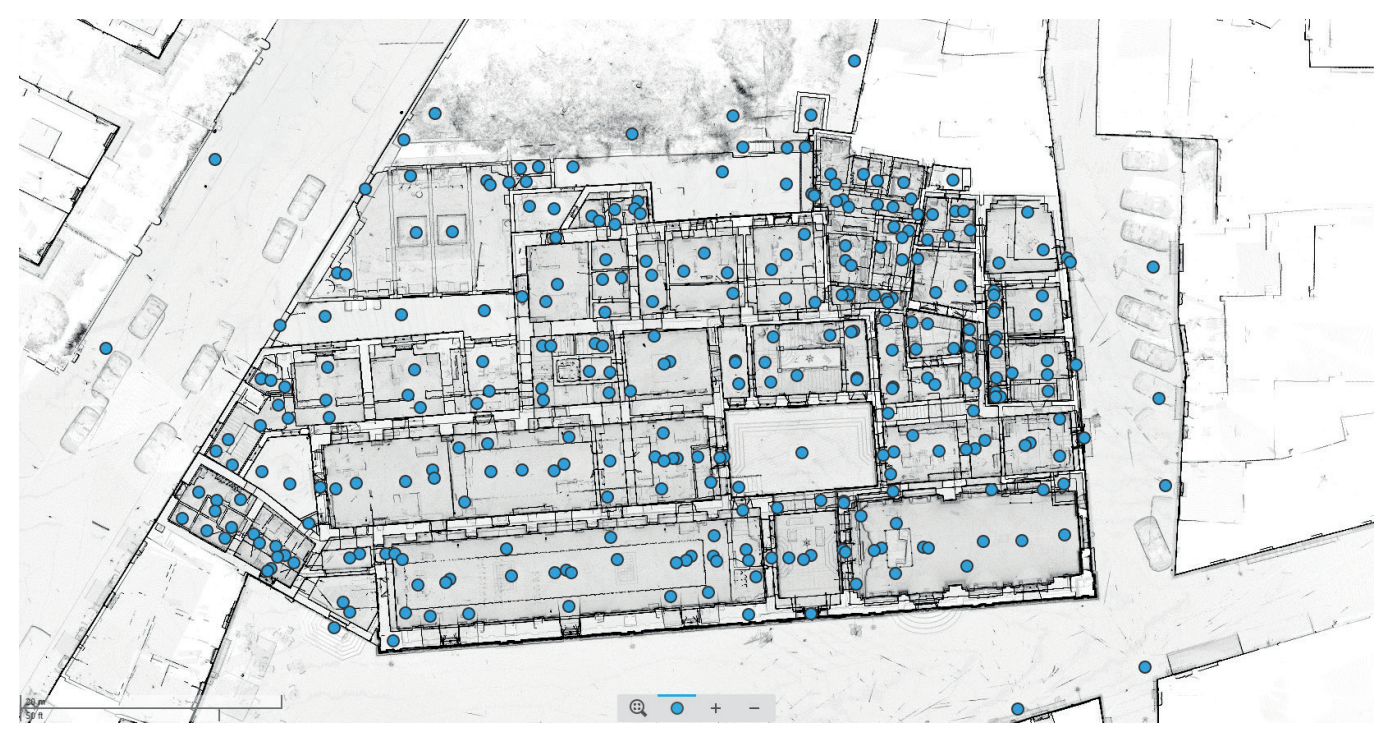

Fig. 3. Vista dall'alto della nuvola di punti dell'ex Ospedale dello Spirito Santo a Lecce.

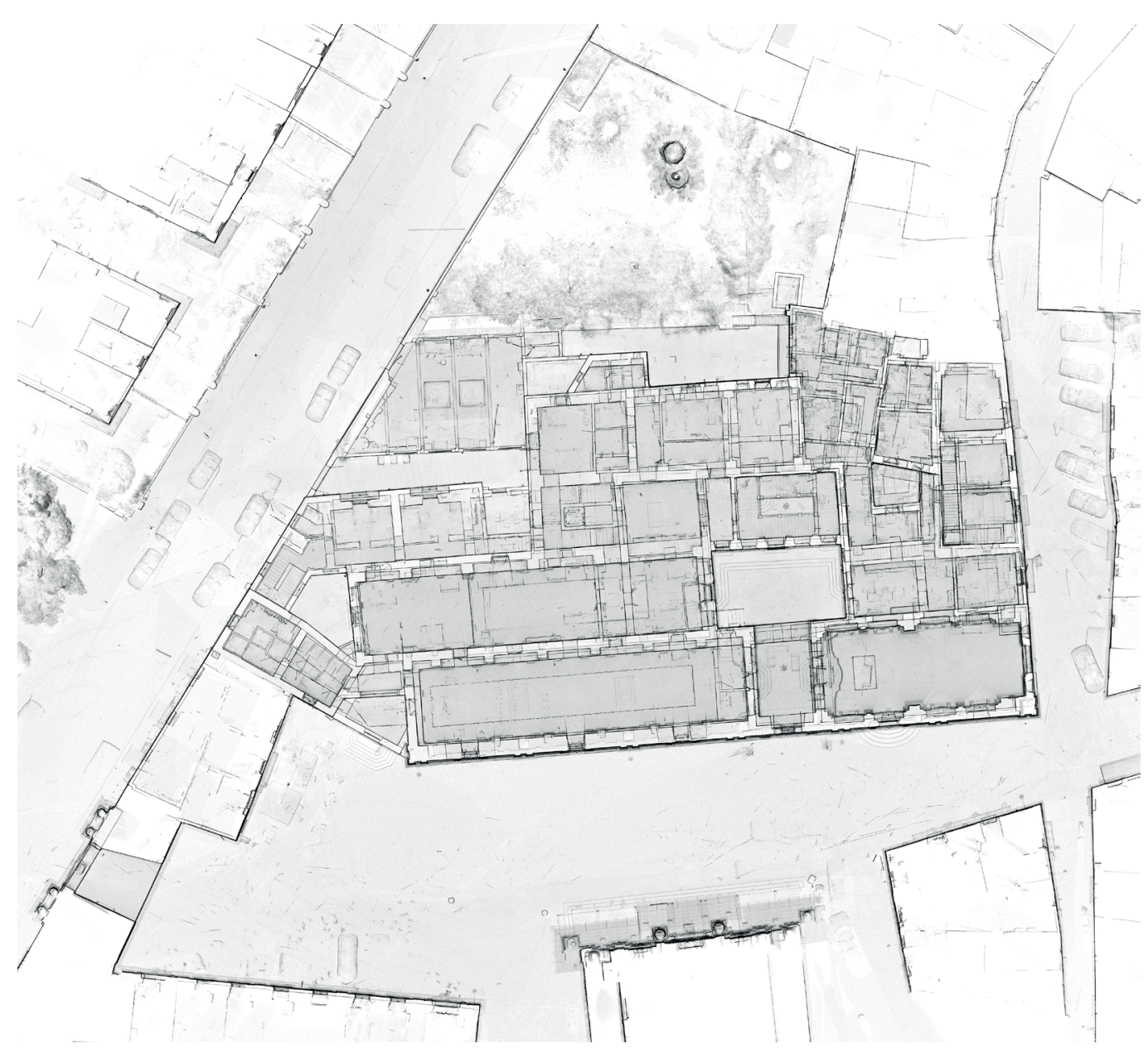


l'Analisi della vulnerabilità e previsioni interventi volti al miglioramento sismico dell'Complesso ex Ospedale dello Spirito Santo a Lecce [4].

II plesso oggetto dell'analisi - sede attuale degli uffici della stessa Soprintendenza - costituisce l'unico esempio di architettura civile ospedaliera rinascimentale nella città di Lecce (fig. I). Voluto da Giovanni d'Aymo - insieme alla chiesa del Rosario ed al convento dei domenicani che lo fronteggiano - assume le attuali fattezze nel I 548 per opera e su disegno di Giangiacomo dell'Acaya - noto architetto di fortificazioni - autore in quegli anni di numerosi castelli e sistemi di fortificazioni tra cui quello della stessa città di Lecce, del suo feudo di Acaya ed incaricato da Pedro de Toledo per la ricostruzione delle mura e del castello di Reggio Calabria, successivamente anche di quello di Crotone; sembra che sia intervenuto anche nel Castel Sant'Elmo a Napoli ed abbia disegnato il castello di Capua e molti altri castelli e fortificazioni pugliesi [Cazzato 2015, p. 59l; D'Ercole 1999, pp. 21-34].

L'Ospedale dello Spirito Santo, indicato inizialmente come xenodochium ospizio per poveri e pellegrini, diviene solo in un secondo momento hospitales luogo per l'assistenza e il ricovero di poveri, malati e orfani. Espressione di valori umanitari e assistenziali in una struttura sociale priva in quell'epoca dell'autorità civile, queste architetture si diffondono in molti abitati della Terra d'Otranto grazie alla devozione e alla generosità di famiglie facoltose che elargiscono copiose donazioni e ricchi lasciti per il loro sostentamento. Sono nella gran parte dei casi gestiti da ordini religiosi che affiancano alla preghiera, alla meditazione e ai riti sacri anche l'assistenza e la protezione dei poveri e degli infermi. [Caputo 20 I6, p. 80]

Uno studio approfondito in merito alle fasi costruttive non è stato ancora condotto; sono documentati solo alcuni degli interventi più recenti.

Risulta infatti che nel 1872 vengono collocati sull'edificio cinquecentesco due quadranti dell'orologio elettrico di Giuseppe Candido premiato all'Esposizione Universale di Parigi del I 867 per la pila che ne azionava i meccanismi. Un quadrante dell'orologio tuttora conservato è sul prospetto principale, l'altro poto nel cortile interno è rimosso in occasione della costruzione del nuovo scalone d'ingresso.

La struttura ospedaliera rimane in funzione sino al 1898 quando viene trasferita nella nuova sede cittadina intitolata a Vito Fazzi. Rientrato tra i beni demaniali l'ospedale diviene sede della Direzione Compartimentale Coltivazione Tabacchi ed è dotato di un ingresso agli uffici realizzato su disegno di Pierluigi Nervi che in quegli anni realizza in città il Magazzino Concentramento Greggi con la sua Impresa Società per Costruzioni Ing. Nervi \& Nebbiosi [Monte 2012, pp. 228-229]. Le due grandi gallerie del piano terra, sale ex infermerie, ven-

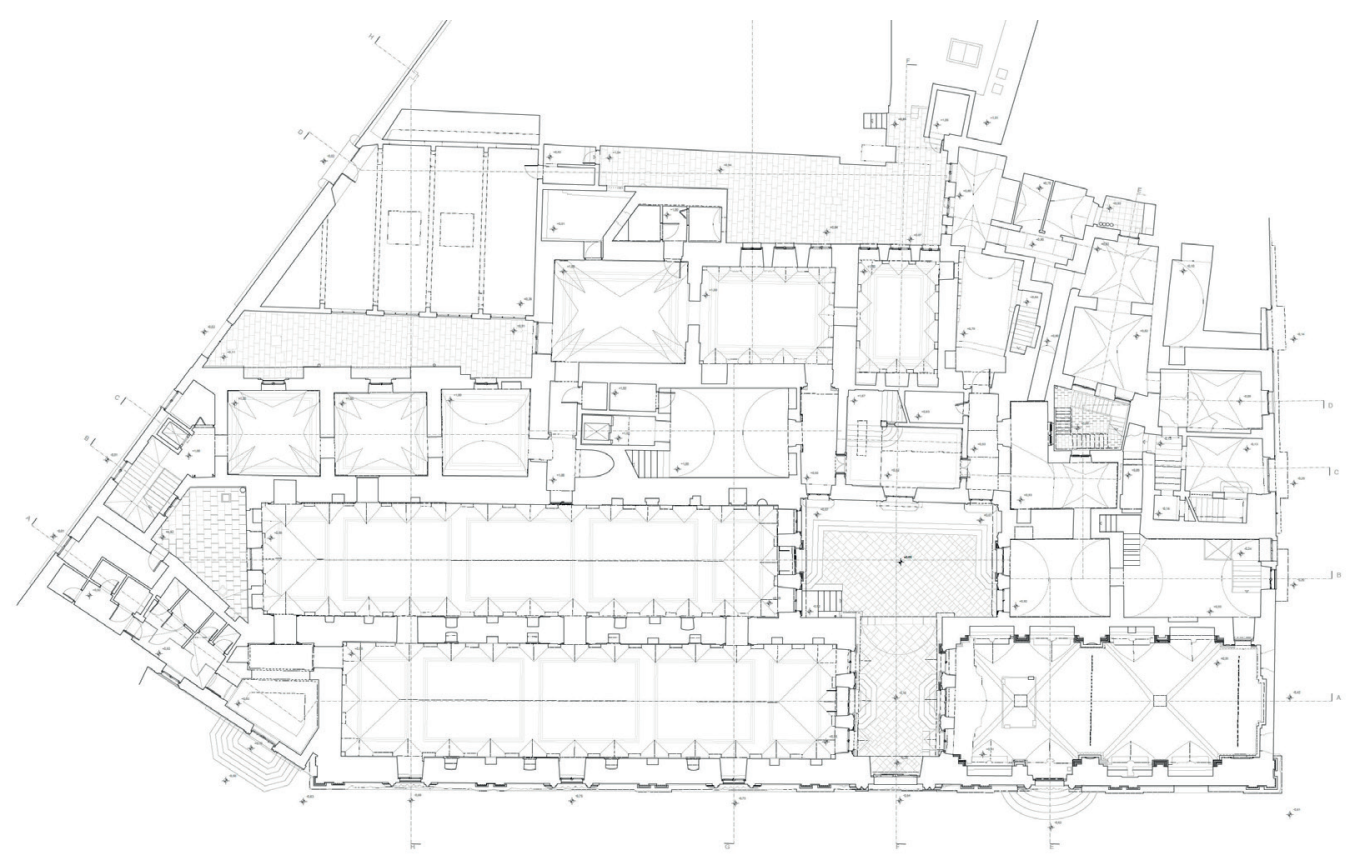


Fig. 5 Prospetto su via Giuseppe Libertini dell'ex Ospedale dello Spirito Santo a Lecce.

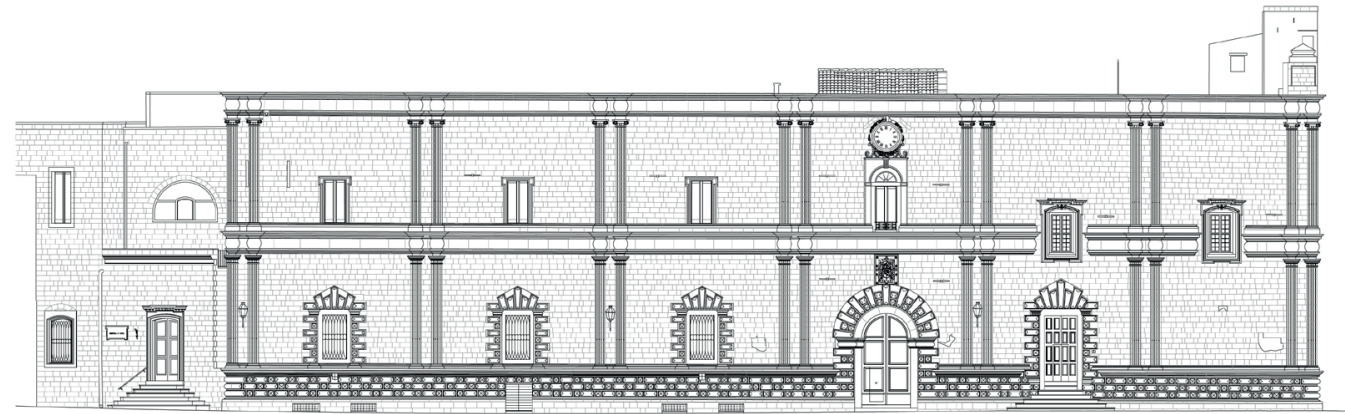

gono utilizzate sino al 20 I I come sala cinematografica e solo nel 20 I6, divenuto sede della Soprintendenza, cominciano i lavori di restauro finanziati con fondi ordinari del Mibact e con Fondi PON FESR 20I4-2020 [5].

Obiettivo principale dell'analisi promossa dalla Soprintendenza è redigere un supporto conoscitivo in grado di assicurare con sufficiente accuratezza una completa descrizione stereometrica del complesso architettonico sulla cui base valutare poi la vulnerabilità del manufatto al fine di avviare azioni di miglioramento che ne riducano il rischio sismico.

Nell'estate 2020 si è avviata la campagna di rilievi dell'intero complesso che si sviluppa su due livelli cui si aggiungono i locali interrati e quelli posti al livello delle terrazze. Al nucleo cinquecentesco, costituito dalle grandi gallerie del piano terra e del piano superiore, si aggiungono poi gli ambienti ammezzati ed una serie di locali di realizzazione più recente alcuni dei quali non ancora completamente recuperati.

L'intero plesso si compone al piano semi-interrato di due grandi ambienti con gli archivi ed un ossario sottostante la chiesa e già rilevato nel 2016 in occasione del suo rinvenimento e oggi accessibile attraverso una botola integrata nella pavimentazione. Al piano terra due grandi gallerie, la chiesa con accesso dall'atrio e dall'esterno e oltre l'atrio il cortile ridottosi nella sua profondità a seguito della costruzione del citato scalone d'ingresso. Fattura coeva alle grandi gallerie sembrano avere i locali alle spalle dello scalone coperti da volte a padiglione lunettate; di fattura successiva appaiono gli ambienti fronteggianti via Galateo al civico 2 e 2a, quelli ricavati a ridosso del circuito murario cittadino lungo via Adua e il secondo ingresso su via Libertini sulla cui targa si legge ancora la scritta "Monopolio di Stato". II secondo piano ripropone una distribuzione simile a quella del sottostante piano terreno ad eccezione del vano della chiesa che è a doppia altezza.

Il fronte principale con bugne nella parte basamentale ed un doppio ordine di paraste binate è sul principale corso cittadino, corso Vittorio Emanuele, all'ingresso del centro storico appena superata Porta Rudiae, una delle porte urbiche ancora conservate. Fronte secondario è quello di via Galateo su cui si affaccia la parte absidale della chiesa che conserva tratti cinquecenteschi solo nella soluzione d'angolo mentre le restanti porzioni dei fronti hanno connotati

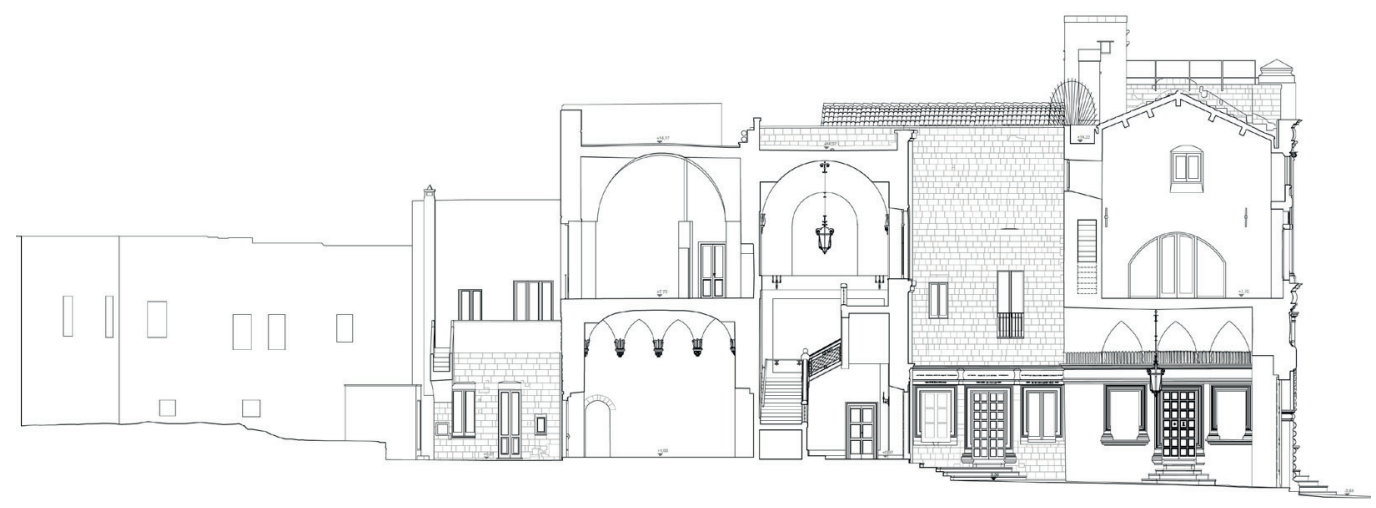


Fig. 7 Sezione delle gallerie dell'ex Ospedale dello Spirito Santo a Lecce.

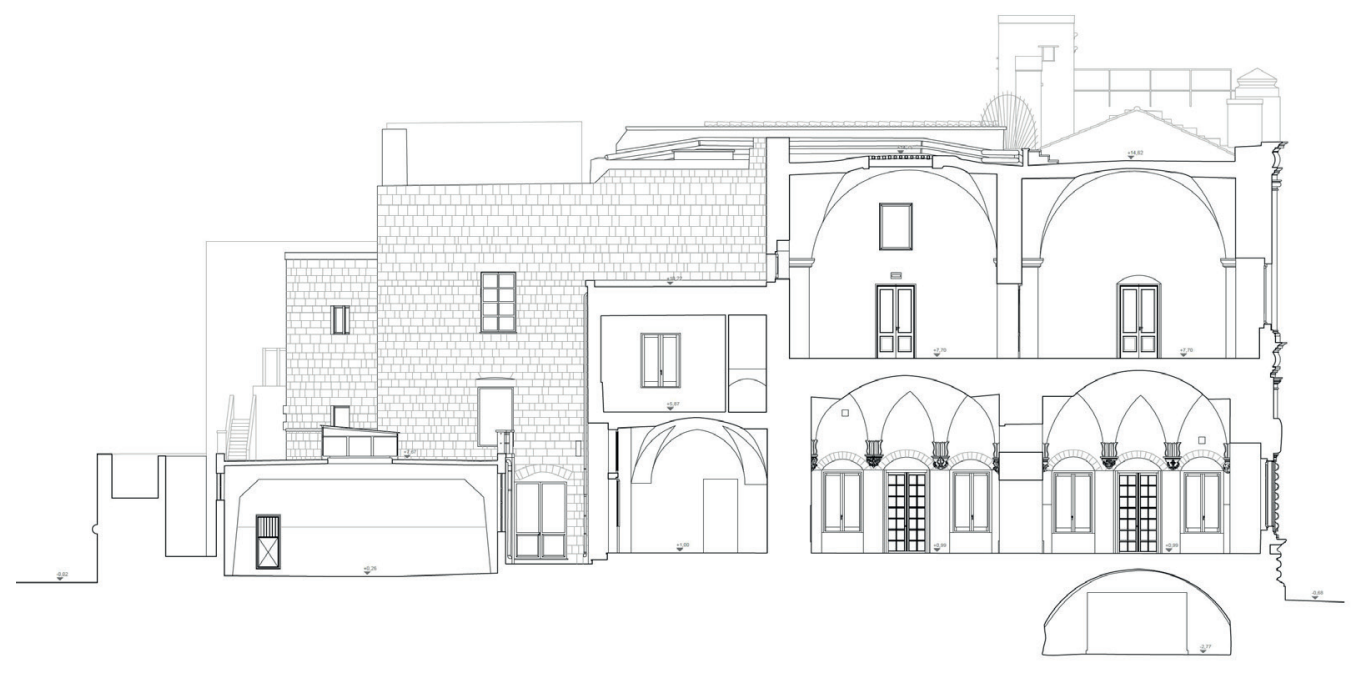

più recenti. Una piccola porzione del complesso si affaccia lungo il circuito murario cinquecentesco di via Adua occupata in gran parte dal giardino di cui rimangono poche tracce di aiuole e un piccolo belvedere risalenti alla trasformazione più recente in giardino pensile. L'intero complesso consta di 2 grandi vani interrati, 54 vani a piano terra, 50 vani a primo piano e 3 vani al livello delle terrazze e, oltre al cortile d'ingresso, di 5 pozzi luce e 6 vani scala, per un numero complessivo di circa 120 vani di diverse dimensioni e forme per una superficie complessiva coperta di 3.9 I 5,00 mq. Sul fronte delle mura ci sono infine il giardino ed un'ampia autorimessa di fattura recente.

II rilievo, interamente condotto con tecnologia laser scanner, è stato integrato dalla fotogrammetria digitale aerea per le porzioni delle coperture non accessibili e si sono individuate strategicamente le posizioni delle singole stazioni di acquisizione laser e degli oltre 500 targets disposti in modo da assicurare una registrazione ottimale delle varie nuvole e ridurre al minimo l'utilizzo di punti naturali [Apolloni et al. 20 I32; Docci 2005; Barni et al. 2020; Chiavoni et al. 20 I I; Miceli et al. 2020; Parrinello et al. 2020]. L'intero plesso è suddiviso in settori sui diversi livelli ed il sistema atrio - cortile - scalone d'ingresso è il settore utilizzato quale ossatura portante e strutturante dell'intero rilievo su cui si sono collegati gli altri settori. Per le acquisizioni si è utilizzato il laser scanner M70 della ditta Faro con circa 320 acquisizioni in sei giorni complessivi di attività di campagna e realizzate per economia di tempo quasi esclusivamente senza la ripresa fotografica e con risoluzioni differenti a seconda si trattasse di interni o di esterni ed in base alle dimensioni degli ambienti e delle caratteristiche degli apparati decorativi degli stessi (fig. 2). L'ambiente della chiesa in particolare con i ricchi apparati decorativi ha richiesto una qualità di dettaglio maggiore per poter restituire con maggiore cura gli elementi che erano stati oggetto di una specifica attività di rilievo con tecniche di fotogrammetria digitale prima degli attuali interventi di restauro [Cacudi, Rossi 2017, pp. 449-157].

La restituzione grafica dellintero complesso, in scala di rappresentazione $1 / 100$, ha previsto 5 livelli planimetrici, 3 fronti edilizi e 8 sezioni passanti negli ambienti più significativi (figg. 4-8). La qualità dei dati di rilievo e soprattutto l'accuratezza delle tecnologie oggi a disposizione forniscono una descrizione stereometrica completa del manufatto aprendo a nuovi ambiti di applicazioni in linea con la strategia di salvaguardia del patrimonio culturale dal rischio sismico in un territorio oltretutto - quello italiano - fortemente caratterizzato da questi fenomeni.

Le attività di prevenzione e di miglioramento da fenomeni sismici - non potendosi nel caso di beni tutelati attuare un vero e proprio adeguamento - non può che essere realizzato nel rispetto della natura del bene e quindi della sua più completa conoscenza, in una logica di prevenzione e non di emergenza. 


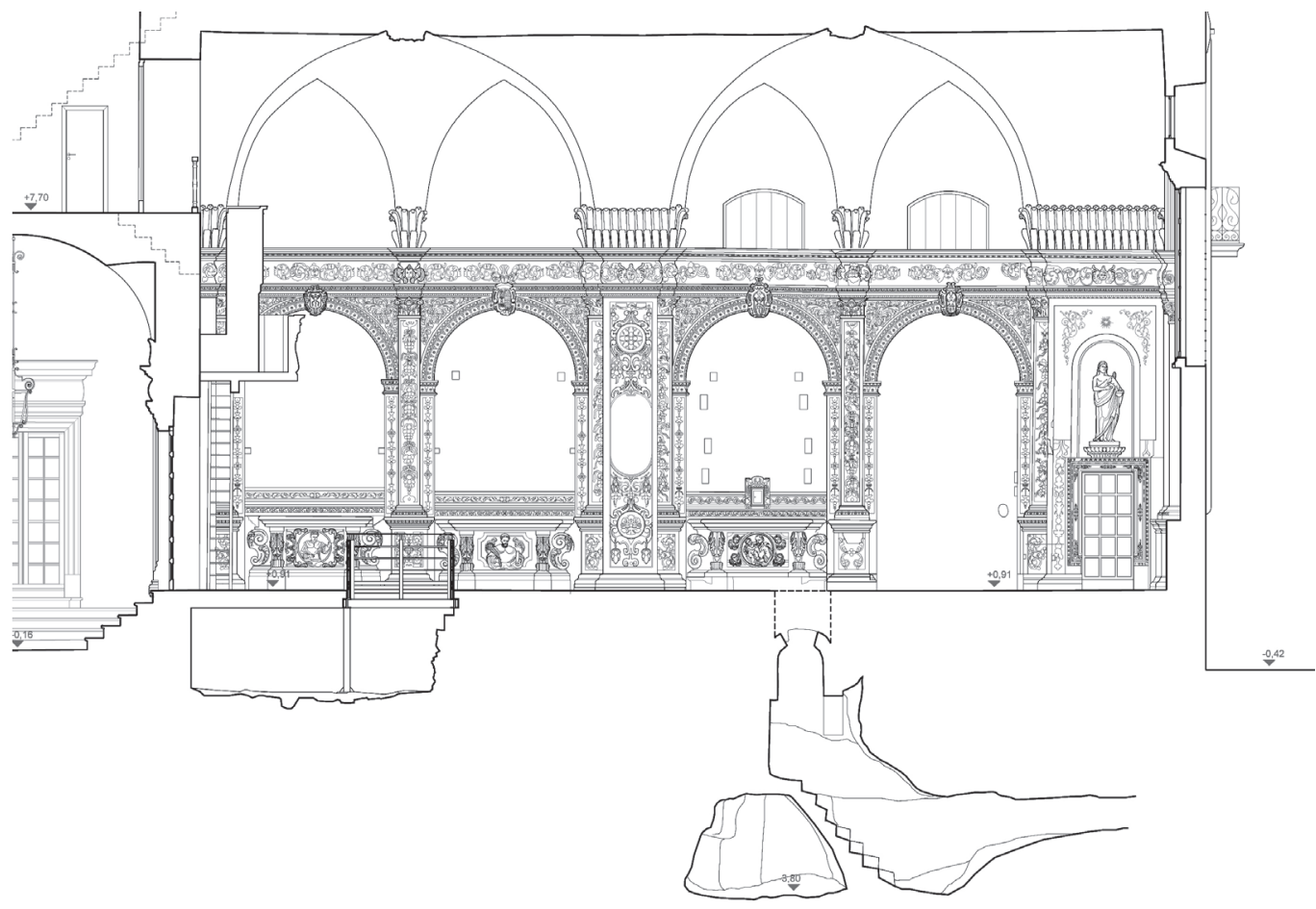

\section{Note}

[I] Introdotte con Decreto del Ministero delle Infrastrutture e dei trasporti il I4 gennaio 2008.

[2] Si rimanda al testo completo ed in particolare a pag. 19

[3] Gazzetta Ufficiale, Serie Generale, n. 297 del 21 dicembre 2016, Suppl. Ordinario n. 57.

[4] Lo Studio Associato COMES di Firenze si è occupato della analisi della vulnerabilità e della previsione degli interventi volti al miglioramento sismico, mentre l'AESEI Architectural \& Engineering Survey of Environment and Infrastructures S.r.l., Spin-Off del Politecnico di Bari, si è occupata del rilievo laser scanner dell'intero plesso dell'Ex Ospedale dello Spirito Santo.

[5] I lavori sono stati eseguiti sotto la direzione dell'arch. Cacudi, funzionario Mibact della Soprintendenza Archeologia Belle Arti e Paesaggio per le province di Brindisi, Lecce e Taranto.

\section{Riferimenti bibliografici}

Apollonio F.I., Gaiani M., Sun Z. (20/3). 3D Modeling and data enrichment in digital reconstruction of architectural heritage. In International Archives of the Photogrammetry, Remote Sensing and Spatial Information Sciences, Volume XL-5/M2, 20I 3, XXIV International CIPA Symposium, 2 - 6 September 2013, pp. 43-487. Strasbourg, France.

Barni R., Bianchini C., Inglese C. (2020). Il duomo di Orvieto. Rilievo integrato e modellazione. In Arena A., Arena M., Brandolino R.G., Colistra D., Ginex G., Mediati D., Nucifora S., Raffa P. (a cura di), Connettere. Un disegno per annodare e tessere, p. 1678 688, Milano: FrancoAngeli.

Cacudi G., Rossi G. (2017). Photo-Modeling for the Documentation of the Restoration Site. The Church of the Complex of the Ospedale dello Spirito Santo in Lecce. In G. Amoruso (Ed.). Putting Tradition into, Practice: Heritage, Place and Design, pp. 449- 157 Cham CH: Springer International Publishing.

Cazzato M. (20 I 5). Biografie. In Cazzato V., Cazzato M. (a cura di). Lecce e il Salento, i centri urbani, le architetture e il cantiere Barocco, Atlante del Barocco in Italia, pp. 59l-660 Roma: De Luca editori d'Arte.

Chiavoni E., Filippa M., Docci M. (20I I). Metodologie integrate per il rilievo, il disegno, la modellazione dell'architettura e della città Roma: Gangemi Edizioni.

D'Ercole F. (200 I). Segni del Rinascimento nella Puglia cinquecentesca: la figura e le opere di Giangiacomo dell'Acaya. In Quaderni dell'Istituto di Storia dell'Architettura, n.s., 33, pp. 2 I-34:24.

Docci M. (2005). Metodologie innovative integrate per il rilevamento dell'architettura e dell'ambiente. Roma: Gangemi Edizioni.

Miceli A., Morandotti M., Parrinello S. (2020). 3D survey and semantic analysis for the documentation of built heritage. The case study of Palazzo Centrale of Pavia University. In VITRUVIO - International Journal of Architectural Technology and Sustainability, June 2020, pp. 65-80. 
Ministero per i beni e le attività culturali. Segretariato Generale (20l0). Linee guida per la valutazione e riduzione del rischio sismico del patrimonio culturale. Roma: Gangemi Editore.

Monte A. (2012). Le opere del Monopolio di Stato e i magazzini dei Concessionari del tabacco nel Salento tra storia, recupero e patrimonio industriale. In Del Prete R. (a cura di). Dentro e fuori la fabbrica. II tabacco in Italia tra memoria e prospettive, pp. 228-229 Milano: FrancoAngeli.

Parrinello S., Picchio F., Dell'Amico Anna, Malusardi C. (2020). Le mura di Cartagena de Indias tra sperimentazione metodologica e protocolli operativi. Strumentazioni digitali a confronto per lo studio del sistema difensivo antonelliano. In Navarro Palazón, García-Pulido (Ed.). Defensive Architecture of the Mediterranean, FORTMED 2020, pp. 4I 5-422 Granada.

\section{Autori}

Marco Aprea, Architetto, collaboratore di AESEI S.r.l., marco.apreal99 I@gmail.com

Giovanna Cacudi, Funzionario Mibact per le province di Brindisi e Lecce, giovanna.cacudi@beniculturali.it Gabriele Rossi, Politecnico di Bari, gabriele.rossi@poliba.it

Francesca Sisci, Politecnico di Bari, francesca_sisci@icloud.com

Per citare questo capitolo: Aprea Marco, Cacudi Giovanna, Rossi Gabriele, Sisci Francesca (202I). Rilievo dell'ex Ospedale dello Spirito Santo a Lecce per la valutazione e riduzione del rischio sismico/Survey of Ex Ospedale dello Spirito Santo in Lecce for Seismic Risk Assessment and Reduction. In Arena A., Arena M., Mediati D., Raffa P. (a cura di). Connettere. Un disegno per annodare e tessere. Linguaggi Distanze Tecnologie. Atti del $42^{\circ}$ Convegno Internazionale dei Docenti delle Discipline della Rappresentazione/Connecting. Drawing for weaving relationship. Languages Distances Technologies. Proceedings of the 42th International Conference of Representation Disciplines Teachers. Milano: FrancoAngeli, pp. 1962-1977. 


\title{
Survey of Ex Ospedale dello Spirito Santo in Lecce for Seismic Risk Assessment and Reduction
}

\author{
Marco Aprea \\ Giovanna Cacudi \\ Gabriele Rossi \\ Francesca Sisci
}

\section{Abstract}

The contribution intends to highlight the role that current survey techniques have in the process of knowledge of an artifact. These techniques can provide a complete stereometric description of the architectural work, the quality and accuracy thus obtained are the basis of the activities of protection and preservation of cultural heritage from seismic risk.

The regulatory framework and guidelines for the evaluation and reduction of seismic risk recognize an important role in the survey operations. Starting from this knowledge base, interventions of protection and improvement of the architectural heritage are promoted, especially for the prevention of seismic risk.

The case study presented is the Complesso dell'ex Ospedale dello Spirito Santo in Lecce, chosen because it is a significant example of prevention and protection by the institutions in charge.

\section{Keywords}

architectural survey, architectural heritage, Ospedale Spirito Santo, Lecce.

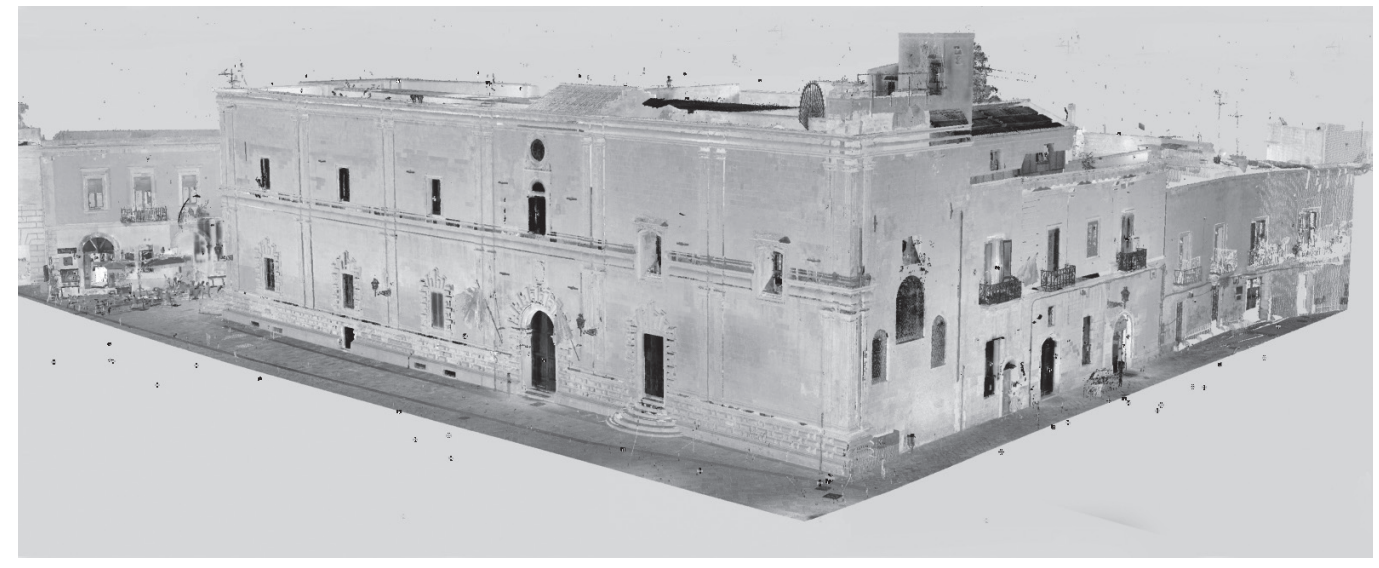


The protection of cultural heritage from seismic risk is part of the prevention activities and it is part of the monitoring program of the state of conservation of protected architectural heritage. The Guidelines for the evaluation and reduction of seismic risk -introduced by the Prime Ministerial Decree of February 9, 20 II in accordance with the New Technical Standards for Construction of 2008 [I]- were drafted "con l'intento di specificare un percorso di conoscenza, valutazione della sicurezza sismica e progetto degli eventuali interventi, concettualmente analogo a quello previsto per le costruzioni non tutelate, ma opportunamente adattato alle esigenze e peculiarità del patrimonio culturale; la finalità è quella di formulare, nel modo più oggettivo possibile, il giudizio finale sulla sicurezza e sulla conservazione garantite dall'intervento di miglioramento sismico. In particolare, il documento è riferito alle sole costruzioni in muratura" [2].

The Knowledge of the building -title of chapter 4 of the guidelines- is "a fundamental prerequisite both for a reliable assessment of current seismic safety and for the choice of an effective improvement intervention". The suggested knowledge path can be carried out in different ways, depending on the accuracy of the survey operations. In particular it is expressly foreseen "the geometric survey of the building at the state of facts, intended as a complete stereometric description of the building body". This type of survey is fundamental to define the geometry of the model to be used in the seismic analysis. In this case we want to use the word stereometry by referring to its Greek etymology to which corresponds the meaning of solid and measurement and therefore the concept of solid measurement. $A$ stereometric description should be understood as a complete knowledge of the geometry of the building body. However, along with the geometric survey, the guidelines prescribe the survey of cracking and deformation phenomena; the historical analysis of events and interventions suffered; the survey of construction techniques, and the state of conservation of materials. This knowledge is the basis for the subsequent stages of assessment of safety and seismic improvement of the building.

In this framework of prevention and monitoring, the Soprintendenza Archeologia Belle Arti e Paesaggio or the provinces of Lecce and Taranto -as part of the fund introduced by Law 232 of December I I, 2016 "Bilancio di previsione dello Stato per l'anno finanziario 2017 e bilancio pluriennale per il triennio 20 I7-2019" al comma I40, lettera h) [3]- has promoted

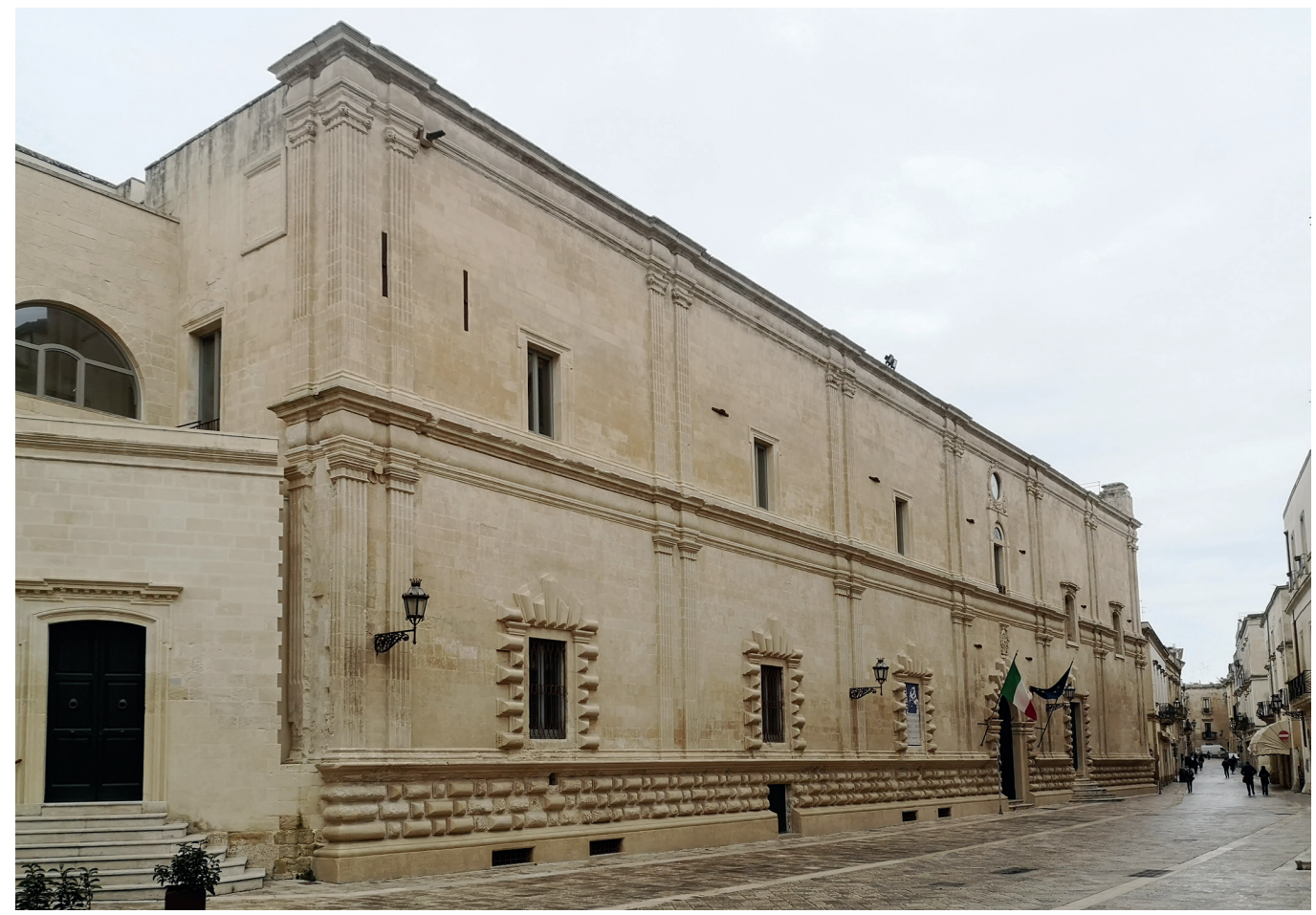



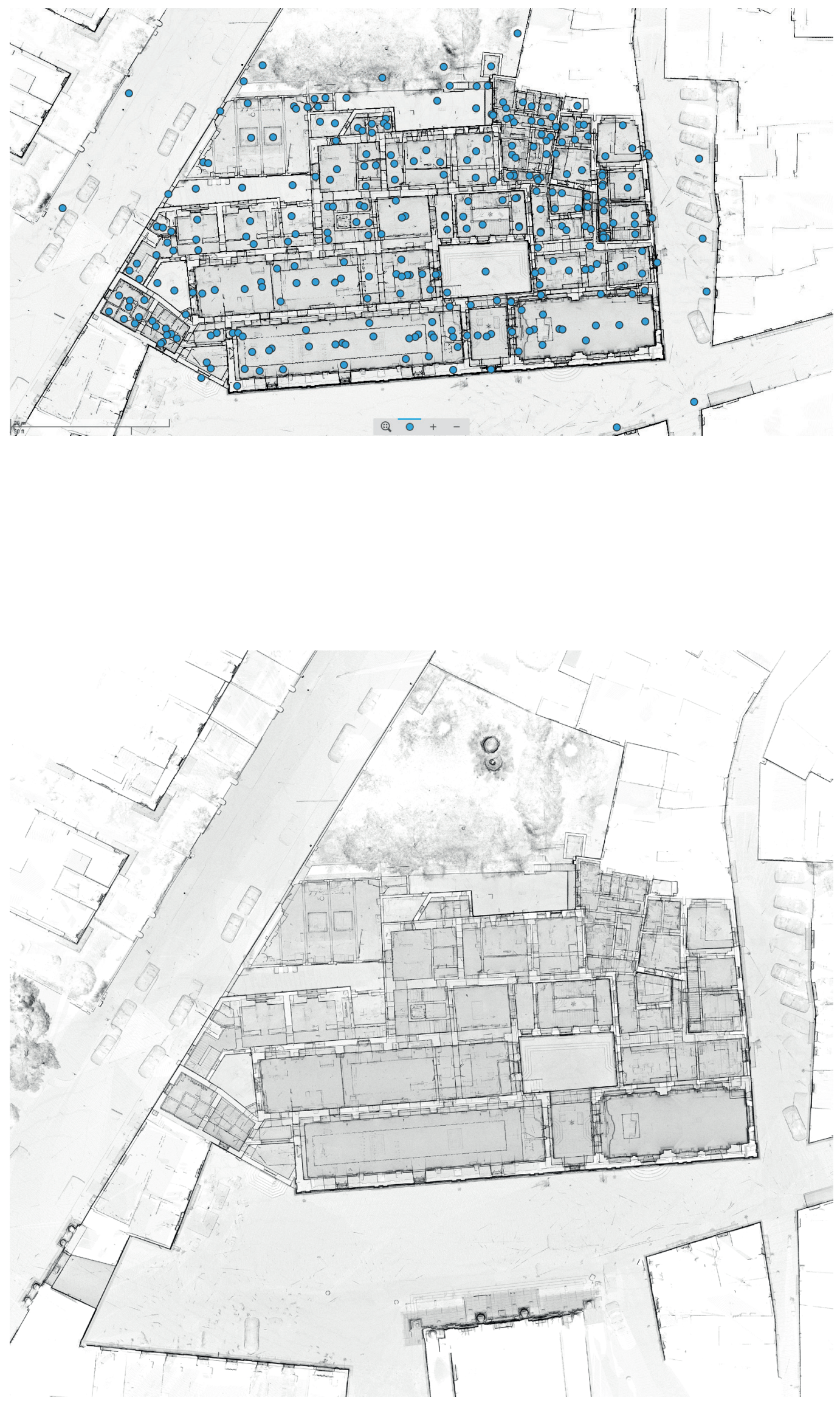
the Analysis of vulnerability and prediction of interventions aimed at seismic improvement of Complesso ex Ospedale dello Spirito Santo in Lecce [4].

The building -the current seat of the offices of the Superintendence- is the only example of civil renaissance hospital architecture in the city of Lecce (fig. I). Wanted by Giovanni d'Aymo -together with the church of the Rosario and the Dominican convent that faces itit assumed its present features in I 548 by the work and design of Giangiacomo dell'Acaya, a well-known architect of fortifications. In the same years, he is the author of numerous castles and systems of fortifications including that of the city of Lecce, that of his feud of Acaya, the reconstruction of the walls, and the castle of Reggio Calabria, commissioned by Pedro de Toledo. Later he worked on the castle of Crotone, and it seems that he also intervened on the Castel Sant'Elmo in Naples and designed the castle of Capua and many other castles and fortifications in Puglia [Cazzato 2015, p. 59I; D'Ercole 1999, pp. 21-34].

The Ospedale dello Spirito Santo, initially indicated as xenodochium: hospice for poor people and pilgrims, only later became hospitales: a place for the assistance and shelter of poor, sick people and orphans. This building is an expression of humanitarian and welfare values in an era without a social structure of a guaranteed type. These architectures spread in many towns of the Terra d'Otranto thanks to the devotion and generosity of wealthy families who gave abundant donations and rich legacies for their sustenance. These hospitals are in most cases managed by religious orders that combine prayer, meditation, and sacred rites with the assistance and protection of the poor and the sick. [Caputo 2016, p. 80]

An in-depth study of the construction phases has not yet been conducted; only some of the most recent interventions have been documented. In 1872 two quadrants of the electric clock designed by Giuseppe Candido were placed on the sixteenth-century building. Candido was awarded a prize at the Universal Exhibition of Paris in 1867 for the battery that operated the mechanism. One quadrant of the clock-still preserved- is on the main facade, the other placed in the inner courtyard was removed during the construction of the new entrance staircase.

The hospital functioned until 1898 when it was transferred to the new city seat named Vito Fazzi. Later it became state property and became the seat of the Direzione Compartimentale Coltivazione Tabacchi. On this occasion, the hospital is equipped with an entrance to the offices made on a design by Pierluigi Nervi, who in those years built in the city the Magazzino Concentramento Greggi with his company Società per Costruzioni Ing. Nervi \& Nebbiosi [Monte 20 I2, pp. 228-229]. The two large galleries on the ground

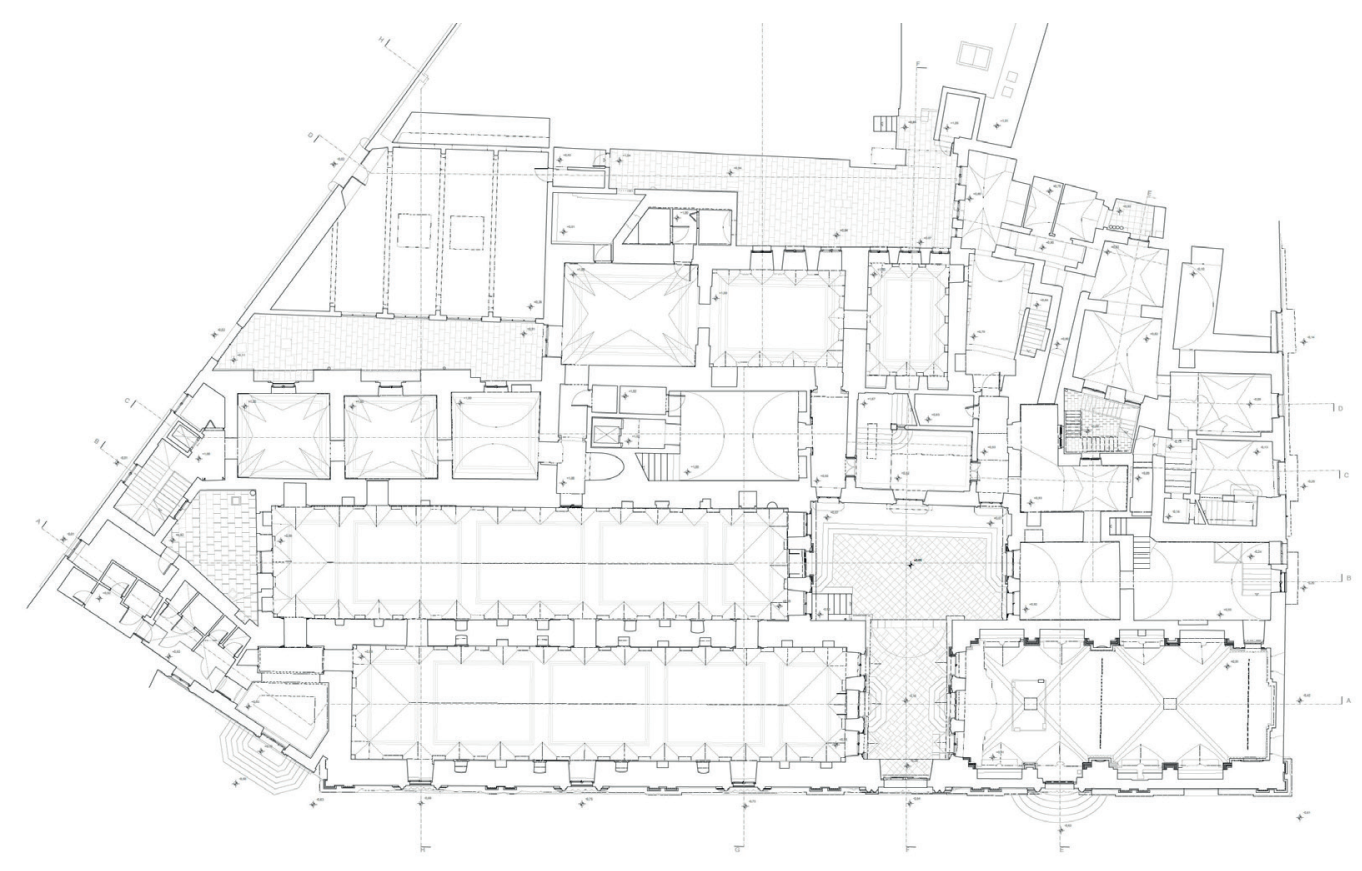


Fig. 5. Facade on Giuseppe Libertini street of the ex Ospedale dello Spirito Santo in Lecce.

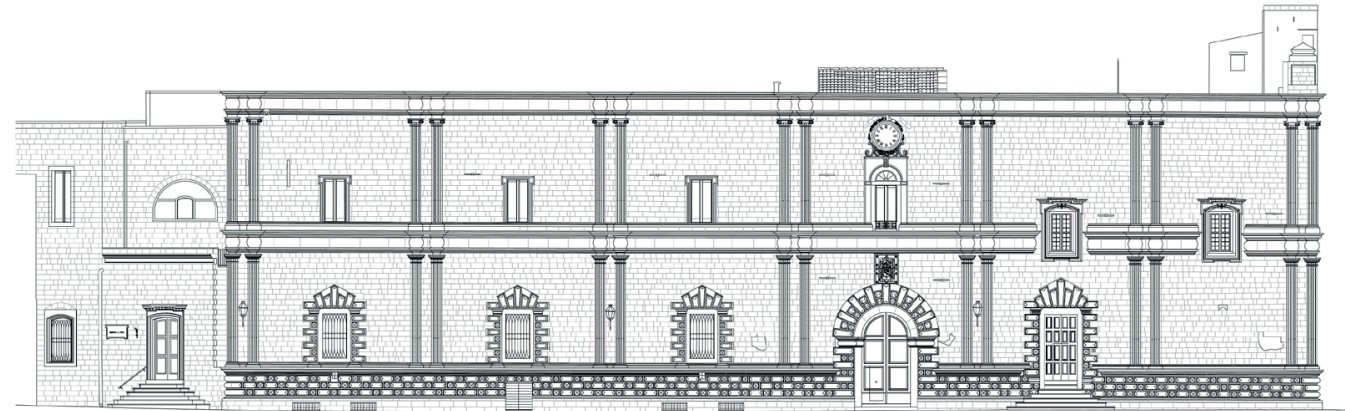

floor -former infirmaries- were used until 201I as movie theaters and only in 2016 the restoration works began, financed with ordinary funds of the Mibact and with PON FESR 20| 4-2020 funds [5].

The main objective of the analyses promoted by the Soprintendenza is to draw up cognitive support. It will be able to ensure with sufficient accuracy a complete stereometric description of the architectural complex based on which then assess the vulnerability of the artifact, and in the end, start improvement actions that reduce the seismic risk.

In the summer of 2020 the campaign of surveys of the entire building, which is spread over two levels, to which are added the underground rooms and those placed on the terraces, was started. To the sixteenth-century block-consisting of the large galleries of the ground floor and upper floor- are added the mezzanine rooms and a series of rooms of more recent construction, some of which have not yet been completely recovered.

The entire complex is composed on the basement floor of two large rooms with the archives and an ossuary underneath the church and already found in 2016, when it was discovered and now accessible through a trap door. The ground floor consists of two large galleries, the church has two entrances from the inner atrium and the street, and beyond the atrium the courtyard that was reduced following the construction of the entrance staircase. The rooms behind the staircase -covered by pavilion vaults-are contemporary to the large galleries. It seems that the rooms facing via Galateo at number 2 and 2a, the rooms obtained behind the city wall along via Adua, and the second entrance on via Libertini -on which there is a plate with the inscription 'Monopolio di Stato'- were built later. The second floor has a distribution similar to that of the ground floor except for the church room which is double height.

The main front is on Corso Vittorio Emanuele -at the entrance of the historical center just after Porta Rudiae- and it is ashlar-worked in the basement part and is marked by a double order of coupled pilasters. The secondary front is attested on via Galateo, on which the apsidal part of the church overlooks. Only in the corner solution are preserved

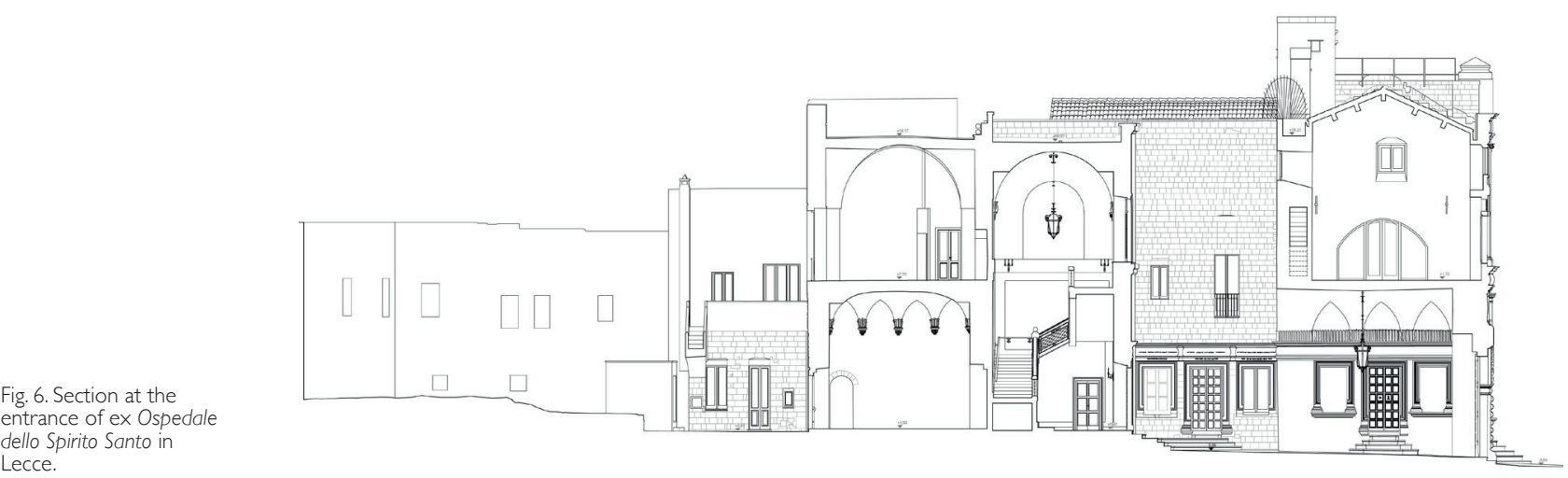

Fig. 6. Section at the entrance of ex Ospedale dello Spirito Santo in Lecce. 


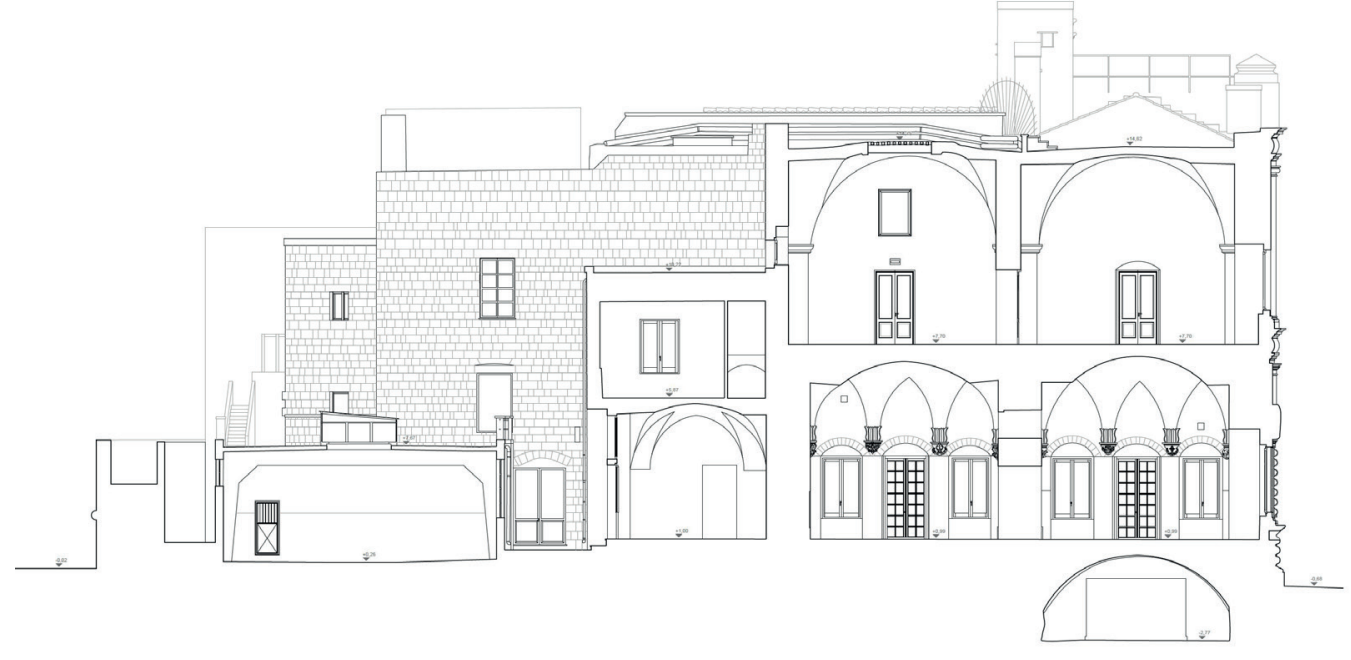

sixteenth-century characteristics, while the remaining portions of the fronts have more recent connotations. A small portion of the complex overlooks along the sixteenth-century boundary wall of Via Adua, which is occupied largely by the garden in which remain a few flower beds and a small belvedere dating back to the most recent transformation into a roof garden.

The entire complex consists of 2 large underground rooms, 54 rooms on the ground floor, 50 rooms on the second floor, and 3 rooms on the level of the terraces. In addition to the entrance courtyard, there are 5 light wells and 6 stairwells, for a total number of about 120 rooms of different sizes and shapes that make up a total covered area of 3915.00 square meters. On the front of the city walls, there are also a garden and a large garage of recent workmanship.

The survey was conducted entirely with laser scanner technology, then integrated by aerial digital photogrammetry for the covers. To begin with, the positions of the individual laser acquisition stations and of the over 500 targets were strategically identified and arranged to ensure optimal registration of the various point clouds and to minimize the use of natural points. [Apolloni et al. 20132; Docci 2005; Barni et al. 2020; Chiavoni et al. 20I I; Miceli et al. 2020; Parrinello et al. 2020]. The entire complex was divided into sectors on different levels. The block composed of the atrium -courtyard- entrance staircase has been used as a connection block of the other sectors.

The M70 laser scanner of the Faro company was used for the acquisitions and about 320 scans were carried out in six days. To save time, the scans were carried out almost exclusively without photographs and with different resolutions, depending on the size of the rooms and the characteristics of their decorative apparatuses (fig. 2). The rich apparatus of the church required a higher quality of scanning, to be able to draw with greater care the details that had already been the subject of a specific survey activity -with digital photogrammetry techniques- before the current restoration work [Cacudi, Rossi 2017, pp. 449-157].

The graphic representation of the entire complex, scale I/I00, consists of 5 plans, 3 elevations, and 8 significant sections (figs. 4-8).

The quality of the survey data and above all the accuracy of the technologies available today provide a complete stereometric description of the artifact. This opens up new areas of application in line with the strategy of safeguarding the cultural heritage from seismic risk. The activities of prevention and improvement from seismic phenomena -not being able in the case of protected goods to implement a real adaptation- can only be carried out in respect of the nature of the asset and therefore of its most complete knowledge, in a logic of prevention and not of emergency. 


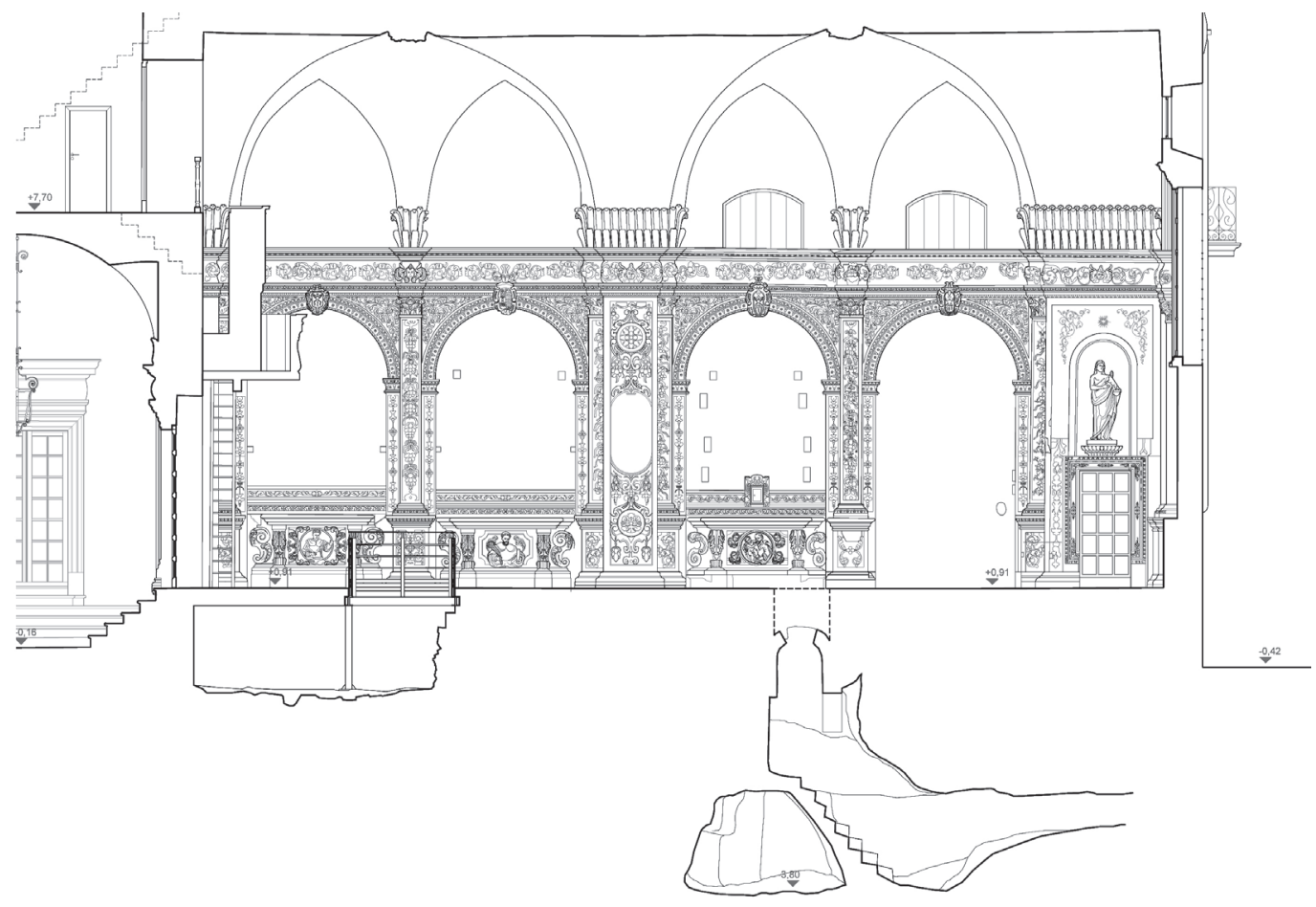

\section{Notes}

[I] Introduced by Decreto del Ministero delle Infrastrutture e dei trasporti of January I4, 2008.

[2] Please refer to the full text and in particular page 19.

[3] Gazzetta Ufficiale, Serie Generale, n. 297 of December 21, 201 6, Suppl. Ordinario n. 57.

[4] Studio Associato COMES of Florence was in charge of the vulnerability analysis and of the forecast of the interventions aimed at seismic improvement. AESEl Architectural \& Engineering Survey of Environment and Infrastructures S.r.l., Spin-Off of the Polytechnic of Bari, was in charge of the laser scanner survey of the whole complex of the Ex Ospedale dello Spirito Santo.

[5] The works were carried out under the direction of arch. Cacudi, Mibact official of the Soprintendenza Archeologia Belle Arti e Paesaggio for the provinces of Brindisi, Lecce and Taranto.

\section{References}

Apollonio F.l., Gaiani M., Sun Z. (2013). 3D Modeling and data enrichment in digital reconstruction of architectural heritage In International Archives of the Photogrammetry, Remote Sensing and Spatial Information Sciences, Volume XL-5/W2, 20I3, XXIV International CIPA Symposium, 2 - 6 September 2013, pp. 43-487. Strasbourg, France.

Barni R., Bianchini C., Inglese C. (2020). Il duomo di Orvieto. Rilievo integrato e modellazione. In Arena A., Arena M., Brandolino R.G., Colistra D., Ginex G., Mediati D., Nucifora S., Raffa P. (a cura di), Connettere. Un disegno per annodare e tessere, p. 1678 1688, Milano: FrancoAngeli.

Cacudi G., Rossi G. (2017). Photo-Modeling for the Documentation of the Restoration Site. The Church of the Complex of the Ospedale dello Spirito Santo in Lecce. In G. Amoruso (Ed.). Putting Tradition into, Practice: Heritage, Place and Design, pp. 449- 157 Cham CH: Springer International Publishing.

Cazzato M. (20 I5). Biografie. In Cazzato V., Cazzato M. (a cura di). Lecce e il Salento, i centri urbani, le architetture e il cantiere Barocco, Atlante del Barocco in Italia, pp. 591-660 Roma: De Luca editori d'Arte.

Chiavoni E., Filippa M., Docci M. (20I I). Metodologie integrate per il rilievo, il disegno, la modellazione dell'architettura e della città. Roma: Gangemi Edizioni.

D'Ercole F. (200I). Segni del Rinascimento nella Puglia cinquecentesca: la figura e le opere di Giangiacomo dell'Acaya. In Quaderni dell'Istituto di Storia dell'Architettura, n.s., 33, pp. 2 I-34:24.

Docci M. (2005). Metodologie innovative integrate per il rilevamento dell'architettura e dell'ambiente. Roma: Gangemi Edizioni.

Miceli A., Morandotti M., Parrinello S. (2020). 3D survey and semantic analysis for the documentation of built heritage. The case study of Palazzo Centrale of Pavia University. In VITRUVIO - International Journal of Architectural Technology and Sustainability, June 2020, pp. 65-80. 
Ministero per i beni e le attività culturali. Segretariato Generale (20l0). Linee guida per la valutazione e riduzione del rischio sismico del patrimonio culturale. Roma: Gangemi Editore.

Monte A. (2012). Le opere del Monopolio di Stato e i magazzini dei Concessionari del tabacco nel Salento tra storia, recupero e patrimonio industriale. In Del Prete R. (a cura di). Dentro e fuori la fabbrica. II tabacco in Italia tra memoria e prospettive, pp. 228-229 Milano: FrancoAngeli.

Parrinello S., Picchio F., Dell'Amico Anna, Malusardi C. (2020). Le mura di Cartagena de Indias tra sperimentazione metodologica e protocolli operativi. Strumentazioni digitali a confronto per lo studio del sistema difensivo antonelliano. In Navarro Palazón, García-Pulido (Ed.). Defensive Architecture of the Mediterranean, FORTMED 2020, pp. 4I 5-422 Granada.

\section{Authors}

Marco Aprea, Architetto, collaboratore di AESEI S.r.l., marco.apreal99 I@gmail.com

Giovanna Cacudi, Funzionario Mibact per le province di Brindisi e Lecce, giovanna.cacudi@beniculturali.it Gabriele Rossi, Politecnico di Bari, gabriele.rossi@poliba.it

Francesca Sisci, Politecnico di Bari, francesca_sisci@icloud.com

To cite this chapter. Aprea Marco, Cacudi Giovanna, Rossi Gabriele, Sisci Francesca (2021). Rilievo dell'ex Ospedale dello Spirito Santo a Lecce per la valutazione e riduzione del rischio sismico/Survey of Ex Ospedale dello Spirito Santo in Lecce for Seismic Risk Assessment and Reduction. In Arena A., Arena M., Mediati D., Raffa P. (a cura di). Connettere. Un disegno per annodare e tessere. Linguaggi Distanze Tecnologie. Atti del $42^{\circ}$ Convegno Internazionale dei Docenti delle Discipline della Rappresentazione/Connecting. Drawing for weaving relationship. Languages Distances Technologies. Proceedings of the 42th International Conference of Representation Disciplines Teachers. Milano: FrancoAngeli, pp. 1962-1977. 